\title{
Shelf life of giant freshwater prawn (Macrobrachium rosenbergii) under different storage conditions
}

\author{
M. Begum 1 , A. A. Pollen, A. W. Newaz ${ }^{2}$ and M. Kamal \\ Department of Fisheries Technology, Bangladesh Agricultural University, Mymensingh-2202, Bangladesh \\ ${ }^{1}$ Marine Fisheries and Technology Station, Bangladesh Fisheries Research Institute, Cox's Bazar-4700, Bangladesh \\ ${ }^{2}$ Department of Animal Husbandry (Fisheries Discipline), Sher-e-Bangla Agricultural University, Dhaka-1207, \\ Bangladesh, Email: awnewaz@yahoo.com
}

\begin{abstract}
The effect of formalin on the organoleptic parameters, biochemical composition and storage quality of iced and frozen stored giant freshwater prawns (Macrobrachium rosenbergii) was investigated. The organoleptic characters such as appearance, textural condition, colour, odour of both formalin added and non-added prawns were evaluated. The quality of non-added prawns was judged good up to first 3 days of iced storage and remained acceptable in terms of commercial standard for processing in the industry up to 6 days. On the other hand, formalin added samples were organoleptically acceptable up to 8 days. The expressible moisture content of both formalin added and non-added prawns continued to increase gradually during 90 days of frozen storage and it was higher in non-added sample. Study of proximate composition at initial storage showed that there were variations in composition between formalin added and non-added samples. At the end of 10 days of iced storage, there was little change in composition in both the cases. To assess the freshness of the prawn samples, TVB-N value and myofibrillar protein solubility were determined. Under iced storage, there was a clear trend of increasing TVB-N value both in formalin added and nonadded samples with higher value in non-added sample. The initial myofibrillar protein solubility of formalin added prawn was $88 \%$ and that of non-added sample was $80 \%$. After 10 days of iced storage, the protein solubility of both the samples decreased to $50 \%$ of their initial value. The solubility of myofibrillar protein of formalin added prawn was lower than non-added sample. Overall loss of freshness took place much faster in non-added prawn sample than the formalin added sample both under iced and frozen storage conditions.
\end{abstract}

Keywords: Freshwater prawn, Organoleptic parameter, Myofibrillar protein, TVB-N value

\section{Introduction}

Fishes as well as shrimps are a highly perishable commodity. After harvesting, it takes several hours to several days to reach to the consumers depending upon the marketing and distribution channels. Therefore, it is essential to take proper step to preserve these fishes until they reach to the consumers. The most common practice of fish preservation in Bangladesh is icing. Kamal and Islam (2000) reported that considerable amount of fishes are wasted due to improper ice use and transportation hazard that count losses to the traders. Therefore, some unscrupulous traders are trying to apply harmful chemicals like formalin for fish preservation. In the wake of food safety issue, formalin contaminated fishes were first confiscated from the traders in 2006 during a drive against adulterated food by the Bangladesh Government.

In recent years, due to non-conformity of exportable aqua-products with international specification, frozen fish export trade in Bangladesh suffered heavy losses in the form of detention or rejection of a part or entire consignment of frozen shrimp or prawn, the cancellation of contract or low price offered by foreign buyers. At times, major reasons behind the rejection were decomposition, followed closely by the presence of pathogenic microorganisms, presence of foreign matter and improper labeling. However, in recent times presence of various steroids, stilbens, formalin, antibiotics like nitrofuran, chloramphenicol, tetracycline and dyes like crystal violet and malachite green in shrimp and prawn samples has become a major concern (Mazid and Mostafa, 2009). Along with local markets, shrimp and prawn products for international markets are now also becoming threatened by unabated use of formalin for preservation purpose.

Formalin is well known as a preservative in medical laboratories, as an embalm fluid and as a sterilizer. Formalin (in highly diluted form) is used as an aquatic chemo-therapeutant. US Food and Drug Administration approved three commercial formalin products as parasiticides and fungicides for use in US food fish aquaculture as combined effect of dilution and rapid degradation of formaldehyde in the aquatic 
environment provide substantial safety factor to all species (Kitchens et al., 1995), but no formalin related compound is approved for preservation purpose. It is, however totally banned in aquaculture applications in Australia, Europe and Japan because of its association with oncogenesis (Matheson, 1981). Ingestion of dilute formalin will cause discomfort in the stomach and mouth. Formalin has the potential to cause cancer, repeated and prolonged exposure increases the risk of cancer of the lung, nasopharynx, oropharynx and nasal passage (Wooster et al., 2005). The International Agency for Research on Cancer classified formalin as carcinogenic to humans when exposed at elevated concentrations. Formalin has also possible links with brain cancer and leukaemia.

Nutritional changes greatly influence the quality of prawn depending on various processing and preservation methods such as frozen storage, iced storage, drying, salting, cooking etc. These changes mainly depend on factors that affect substrate and metabolite concentration in living animal tissue, activity of endogenous enzymes, and natural and post-catch microbiological contamination (Fatima and Qadri, 1985; Sikorski et al., 1994). To assess the potentialities of effective utilization of prawn for industrial purpose and also to determine the changes during storage it is necessary to know the composition of material under investigation. There are a number of chemical parameters widely used to assess the degree of freshness of prawn which include determination of TVB-N value and myofibrillar protein solubility. The changes of these biochemical parameters in prawn are closely related to organoleptic changes. The present study was conducted to evaluate the changes in organoleptic parameters, composition and freshness quality of formalin added and non-added prawn samples in iced storage and frozen condition. The outcomes of this research may help build awareness among the relevant stakeholders not to use formalin in aquatic products.

\section{Materials and Methods}

Prawn samples with an average body weight of $33.6 \pm 0.2 \mathrm{~g}$ and $14-16 \mathrm{~cm}$ size were collected from local market of Bangladesh Agricultural University (BAU) campus and transported to the laboratory of Department of Fisheries Technology, Faculty of Fisheries, BAU, Mymensingh in an insulated box in ice. One group of prawn sample was added with $5 \%$ formalin for 5 minutes and then stored in ice in an insulated box; another group of prawn was stored in ice without formalin treatment. For determining the expressible moisture content, prawn samples (formalin added and non-added) were stored in frozen condition at $-20^{\circ} \mathrm{C}$.

Assessment of organoleptic qualities: The organoleptic assessment was performed by using the structured scaling method known as Quality Index Method (QIM). In QIM, a number of important attributes such as appearance, shell and carapace colour, odour, firmness, etc. are measured on a limited scale and the scores are averaged to provide an index (Bremner et al., 1987). These organoleptic characteristics and changes in quality were checked at every 24 hour interval up to 10 days of iced storage.

Expressible moisture test: To evaluate the physical changes occurred in formalin added and non-added samples kept at $-20^{\circ} \mathrm{C}$, expressible moisture was determined according to the method described by $\mathrm{Ng}$ and Hasegawa (1987) with certain modifications. At selected time intervals, frozen samples were cut into number of pieces. About $1.0 \mathrm{~g}$ of muscle was placed between double layers of filter paper and pressed at $1 \mathrm{~kg} / \mathrm{cm}^{2}$ for 3 minutes. Decrement in weight was measured and the ratio of decrement in the original weight was expressed as expressible moisture (\%).

Proximate composition analyses: Formalin added and non-added prawn samples were ground in an electric blender to produce a homogenous mixture before biochemical analyses. Proximate composition analyses were carried out for moisture, crude protein, lipid and ash according to the methods given in AOAC (1980) with certain modifications. Analyses were done at the initial storage time and at the end of 10 days of iced storage.

Determination of Total Volatile Base Nitrogen (TVB-N): TVB-N was determined according to the standard method described by EC (1995) with some modifications. Estimation of TVB-N was done at every 2 days interval up to 10 days of iced storage. 
Determination of myofibrillar protein solubility: Myofibrillar protein solubility of both formalin added and non-added samples were carried out everyday up to 10 days of ice storage. Myofibrils were prepared from ordinary and dark muscles immediately after excision according to the method of Perry and Grey (1956). Two $\mathrm{ml}$ of myofibrillar suspensions $(5 \mathrm{mg} / \mathrm{ml}$ ) were homogenized with $2 \mathrm{ml}$ of $1 \mathrm{M} \mathrm{KCl}$ plus 100 $\mathrm{mM}$ phosphate buffer $\left(\mathrm{p}^{\mathrm{H}}\right.$ 7.0) using a homogenizer. The homogenate was then stored at refrigeration temperature $\left(4^{\circ} \mathrm{C}\right)$ overnight. The suspension was centrifuged for 30 minutes at $4000 \times \mathrm{g}$ in cool condition. The protein in supernatant was determined by Biuret method (Cornall et al., 1949).

Bacteriological analyses: The media were prepared in the laboratory as per direction of Cowan and Steel's Manual for Identification of Medical Bacteria (edited by Barrow and Felthham, 1993) with the help of DIFCO Manual of Dehydrated Culture Media and Reagents (Anon, 1972). Bacteriological analyses of ice stored formalin added and non-added whole prawns were done at every 2 days interval up to 10 days. At first, both samples were weighed and then ground by using blender with previously prepared physiological saline $(0.85 \% \mathrm{NaCl})$ as diluent. Then desired dilutions were made according to decimal dilution method. Strict aseptic procedures were followed in every step of analysis.

\section{Results and Discussion}

Organoleptic quality assessment: The organoleptic qualities of $M$. rosenbergii during iced storage (without formalin) are presented in Table 1. The qualities were evaluated by grading the prawn using the score from 0 to 10 based on organoleptic characteristics such as general appearance, odor, carapace texture, carapace color, eye, shell color etc. The grade points ranging from 8.5 to 10.0 were considered as excellent; $6.5-8.4$ as very good; 4.5 to 6.4 as good 3.6 to 4.4 as acceptable; 2.6 to 3.5 as bad and 0 to 2.5 as very bad condition in case of raw prawn. The organoleptic characteristics such as appearance, textural condition, color and odor indicated that prawn without formalin were in very good condition during the first 24 hours in ice. The samples gradually lost the characteristics of freshness with the lapse of storage period. However, they were judged of good quality up to first 3 days and acceptable

Table 1. Changes in organoleptic qualities of prawn (Macrobrachium rosenbergii) during 10 days of iced storage

\begin{tabular}{|l|l|c|c|}
\hline $\begin{array}{c}\text { Storage } \\
\text { period } \\
\text { (days) }\end{array}$ & \multicolumn{1}{|c|}{ Organoleptic qualities } & $\begin{array}{c}\text { Grade } \\
\text { point }\end{array}$ & $\begin{array}{c}\text { Overall } \\
\text { quality }\end{array}$ \\
\hline $1^{\text {st }}$ day & $\begin{array}{l}\text { Fresh, bright, shining and iridescent, firm, consistent and elastic texture with } \\
\text { characteristics of white color of flesh. Neutral odor and color of shell. }\end{array}$ & 9.5 & Excellent \\
\hline $2^{\text {nd }}$ day & $\begin{array}{l}\text { Slight loss of brightness but the surface is still shining and iridescent. Firm } \\
\text { consistent and elastic texture with characteristics of white color of flesh. } \\
\text { Odor and color of shell is natural. }\end{array}$ & 7.9 \\
\hline $3^{\text {rd }}$ day & $\begin{array}{l}\text { Slight loss of brightness but the surface is still shining and iridescent. Firm } \\
\text { consistent and elastic texture with characteristics of white color of flesh. } \\
\text { Odor and color of shell is natural. }\end{array}$ & 6.8 & Very good \\
\hline $4^{\text {th }}$ day & $\begin{array}{l}\text { Slight loss of brightness. Moderately soft and some loss of elastic texture. } \\
\text { Slight changes in color of flesh and shell odor was neutral. }\end{array}$ & 5.9 & \multirow{2}{*}{ Good } \\
\hline $5^{\text {th }}$ day & $\begin{array}{l}\text { Slight loss of brightness. Some softening in texture. Slight pink color of flesh } \\
\text { and shell but still neutral odor }\end{array}$ & 4.6 \\
\hline $6^{\text {th }}$ day & $\begin{array}{l}\text { Slight dullness and loss of brightness, some softening texture. Slight pink } \\
\text { color of flesh and shell. Slight sour odor. }\end{array}$ & 3.8 & Acceptable \\
\hline $7^{\text {th }}$ day & $\begin{array}{l}\text { Definite dullness and loss of brightness. Some softening texture. Pink color } \\
\text { of flesh and brownish red of shell. Ammonical odor. }\end{array}$ & 3.1 \\
\hline $8^{\text {th }}$ day & $\begin{array}{l}\text { Definite dullness and loss of brightness. Soft and watery texture. Pink color } \\
\text { of flesh and discolor of shell with ammonical odor. }\end{array}$ & 2.7 \\
\hline $9^{\text {th }}$ day & $\begin{array}{l}\text { General appearance is dull. Soft and watery texture, Dull or discolor of flesh. } \\
\text { Shells discolor. Rotten odor. }\end{array}$ & 2.2 \\
\hline $10^{\text {th }}$ day & $\begin{array}{l}\text { Dull/discolor of flesh. Shells discolored, emission of rotten odor. Flesh soft } \\
\text { and watery in texture. }\end{array}$ & Bad \\
\hline
\end{tabular}


(in terms of commercial standard for processing in the industry) up to 6 days of iced storage. On the other hand, formalin added prawn samples stored in ice were found organoleptically acceptable up to 8 days which indicated that keeping time of formalin added prawn in ice increased 2 days more than that of nonadded sample (Table 2). In previous studies, both Macrobrachium rosenbergii and Penaeus monodon were found in organoleptically acceptable condition for 6 to 7 days under iced storage (Kamal et al., 2000). In similar findings, Rahaman (2001) also reported that the fresh shrimp samples stored in ice immediately after harvest were started to lose natural flavor after 3 to 4 days and remained organoleptically acceptable for 10 days.

Table 2. Changes in organoleptic qualities in formalin added prawn (Macrobrachium rosenbergii) during 10 days of iced storage

\begin{tabular}{|c|c|c|c|}
\hline $\begin{array}{l}\text { Storage } \\
\text { period } \\
\text { (days) }\end{array}$ & Organoleptic qualities & $\begin{array}{l}\text { Grade } \\
\text { Point }\end{array}$ & Overall quality \\
\hline $1^{\text {st }}$ day & $\begin{array}{l}\text { Fresh, bright, shining and iridescent, firm, consistent and elastic } \\
\text { texture with characteristics of white color of flesh. Odor and color of } \\
\text { shell was natural. }\end{array}$ & 9.5 & \multirow{3}{*}{ Excellent } \\
\hline $2^{\text {nd }}$ day & $\begin{array}{l}\text { Fresh, bright, shining and iridescent, firm, consistent and elastic } \\
\text { texture with characteristics of white color of flesh. Odor and color of } \\
\text { shell was natural. }\end{array}$ & 9.2 & \\
\hline $3^{\text {rd }}$ day & $\begin{array}{l}\text { Fresh, bright, not so shining, firm, consistent and elastic texture with } \\
\text { characteristics of white color of flesh. Odor and color of shell was } \\
\text { natural. }\end{array}$ & 9.0 & \\
\hline $4^{\text {th }}$ day & $\begin{array}{l}\text { Slight loss of brightness but shining and iridescent. Firm, consistent } \\
\text { and elastic texture with characteristics of white color of flesh. Odor } \\
\text { and color of shell was natural }\end{array}$ & 7.7 & Very good \\
\hline $5^{\text {th }}$ day & $\begin{array}{l}\text { Slight loss of brightness. Moderately soft and some loss of elastic } \\
\text { texture. Slight changes in color of flesh and shell odor were neutral. }\end{array}$ & 6.2 & \multirow{3}{*}{ Good } \\
\hline $6^{\text {th }}$ day & $\begin{array}{l}\text { Slight loss of brightness. Moderately soft and some loss of elastic } \\
\text { texture. Slight pinkish color of flesh and shell odor was neutral. }\end{array}$ & 5.8 & \\
\hline $7^{\text {th }}$ day & $\begin{array}{l}\text { Slight dullness and loss of brightness some softening texture. Slight } \\
\text { pink color of flesh and shell. Slight sour odor. }\end{array}$ & 4.9 & \\
\hline $8^{\text {th }}$ day & $\begin{array}{l}\text { Definite dullness and loss of brightness. Some softening texture. Pink } \\
\text { color of flesh and brownish red of shell. Slight sour odor. }\end{array}$ & 4.0 & Acceptable \\
\hline $9^{\text {th }}$ day & $\begin{array}{l}\text { Definite dullness and loss of brightness. Soft and watery texture. Pink } \\
\text { color of flesh and shell was discolored. Ammonical odor. }\end{array}$ & 3.1 & $\mathrm{Bad}$ \\
\hline $10^{\text {th }}$ day & $\begin{array}{l}\text { General appearance dull. Soft and watery texture. Dull or } \\
\text { discoloration of flesh. Shell discolored. Emission of Rotten odor. }\end{array}$ & 1.9 & Very bad \\
\hline
\end{tabular}

The pattern of changes in organoleptic qualities can roughly be divided into four phases corresponding to the periods of 0 to 1,2 to 6,7 to 8 and 9 to 10 days in ice. In phase I, the prawn just passed the rigor mortis and there was a very little change in texture. At this stage, samples were in very good condition with fresh bright shining and iridescent appearance, firm, consistent and elastic texture, characteristic white flesh color and natural shell odor and color. In phase II (2 to 6 days), there was slight dullness and loss of brightness and slight softening of texture. The color of flesh and shell slightly turned into pink with natural odor. In phase III (7 to 8 days), there was considerable loss of brightness and softening of texture. The flesh was still natural and had no off flavor. In phase IV (9 to 10 days), there was sign of early spoilage with sour odor and the shell became discolored. Samples began to taste stale and its appearance showed obvious sign of spoilage with unpleasant smell. Reilly et al. (1985) reported that prawn (P. monodon) held at normal temperature, lost up to $15 \%$ of their body weight after $16 \mathrm{~h}$ and rejected due to discoloration, strong ammoniac odor and very soft textures. Yamagata and Low (1995) found that the shelf life of $P$. merguiensis caught in Singapore and stored in ice was 4 days. The available reports suggest that the shelf life of shrimp/prawn during iced storage varies from species to species depending upon chemical composition and ambient temperature in which they are kept. The results of the present study demonstrated that the quality of $M$. rosenbergii for export by seafood industry can be maintained in ice up to 6 days without using formalin or any other chemicals. So, the use of formalin in prawn as preservative extends the overall shelf life by few more days. 
Expressible Moisture: A gradual increase in expressible moisture content of formalin added and nonadded prawn was observed throughout the 90 days of frozen storage at $-20^{\circ} \mathrm{C}$ (Fig. 1). After 15 days of frozen storage period, the expressible moisture content reached up to $25 \%$ and $23 \%$ for formalin added and non-added prawn samples, respectively. Finally, at the end of 90 days of storage, expressible moisture content increased up to $46 \%$ for non-added and $40 \%$ for formalin added sample.

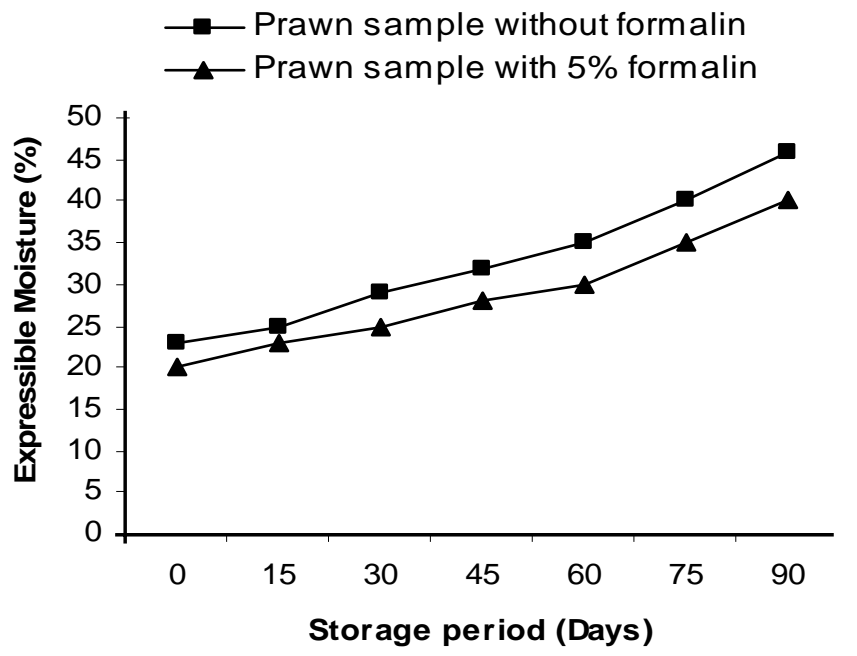

Fig. 1. Changes in expressible moisture content in non-added and formalin added prawns under frozen storage

Expressible moisture is an indicator of muscle's ability to retain water against a gravitational force. The water retention ability of muscle is affected by factors like $\mathrm{pH}$ and ionic strength. Expressible moisture usually reflects the extent of denaturation of the protein and water content of fish muscle under investigation (Suvanich et al., 2000). This phenomenon leads to reduction of flavour agents and nutrition value (Reddy and Srikar, 1991). The chemical changes of protein lead to an increase in drip loss and to an increase in expressible moisture (Yamagata and Low, 1995). As a result, the loss of freshness with softer texture, loss of muscle yield, slight ammonia odor, and poor appearance of the stored prawn can be attributed to this phenomenon. A gradual increase of expressible moisture content of channel catfish was also observed by Ruan and Chen (1998) and Garner et al. (2002) which is similar to present findings.

Proximate composition: The proximate composition of both non-added and formalin added prawn samples is presented in Table 3. The initial moisture, protein, lipid and ash contents of non-added prawn were $78.67,18.53,1.34$ and $0.94 \%$, respectively. At the end of 10 days of iced storage, moisture decreased to $77.80 \%$ and crude protein content also decreased to $18.51 \%$ while lipid and ash content slightly increased. For the convenience of calculation, the protein, lipid and ash contents were determined on dry weight basis. On moisture free basis, protein content decreased considerably from 86.87 to 83.37\%. Both lipid and ash content showed slight increase. The initial composition of formalin added sample showed some variation compared to non-added sample specially with regard to moisture and protein. However, the change in composition due to iced storage was more or less similar both in formalin added and non-added sample.

The decrease in crude protein during 10 days of iced storage in both experiments is due to the formation of free drip accompanied by some sarcoplasmic protein. Tarr (1965) reported that some loss of organic nitrogenous constituents, largely sarcoplasmic protein and inorganic salts with free drip are probable contributing factor of such loss of protein contents in chilled fish. Lipid contents increased slightly in case of non-added prawn sample due to iced storage. But little increase in ash content was observed both in formalin added and non-added samples. The values of proximate composition obtained for $M$. rosenbergii were similar as reported by Babbitt et al. (1974) for prawn, although proximate composition varies greatly from species to species and within the same species depending on size, sex, season and feeding habitat. 
Table 3. Changes in proximate composition of non-added and formalin added prawn during iced storage

\begin{tabular}{|c|c|c|c|c|c|}
\hline Sample & Condition & $\begin{array}{c}\text { Moisture } \\
(\%)\end{array}$ & $\begin{array}{c}\text { Lipid } \\
(\%)\end{array}$ & $\begin{array}{c}\text { Crude } \\
\text { Protein (\%) }\end{array}$ & $\begin{array}{c}\text { Ash } \\
(\%)\end{array}$ \\
\hline $\begin{array}{c}\text { Non-added } \\
\text { prawn }\end{array}$ & Initial & 78.67 & $\begin{array}{c}1.34 \\
(6.28)^{\star}\end{array}$ & $\begin{array}{c}18.53 \\
(86.87)^{\star}\end{array}$ & $\begin{array}{c}0.94 \\
(4.40)^{\star}\end{array}$ \\
\cline { 2 - 6 } & Final & 77.80 & $\begin{array}{c}1.50 \\
(6.75)^{\star}\end{array}$ & $\begin{array}{c}18.51 \\
(83.37)^{\star}\end{array}$ & $\begin{array}{c}1.34 \\
(6.03)^{\star}\end{array}$ \\
\hline \multirow{2}{*}{$\begin{array}{c}\text { Formalin added } \\
\text { prawn }\end{array}$} & Initial & 79.71 & $\begin{array}{c}1.31 \\
(6.44)^{\star}\end{array}$ & $\begin{array}{c}16.78 \\
(82.72)^{\star}\end{array}$ & $\begin{array}{c}1.00 \\
(4.95)^{\star}\end{array}$ \\
\cline { 2 - 6 } & Final & 79.27 & $\begin{array}{c}1.24 \\
(5.98)^{\star}\end{array}$ & $\begin{array}{c}16.50 \\
(79.59)^{\star}\end{array}$ & $\begin{array}{c}1.20 \\
(5.78)^{\star}\end{array}$ \\
\hline
\end{tabular}

* Values within the parenthesis are on dry weight basis.

Total Volatile Base Nitrogen (TVB-N): Studies were conducted on the changes in TVB-N value in formalin added and non-added prawn in 10 days of iced storage. Changes in TVB-N values in both treatments under iced storage are presented in Fig. 2. In non-added prawn, the initial TVB-N value was $10.0 \mathrm{mg} / 100 \mathrm{~g}$ which increased considerably with the lapse of storage period. TVB- $\mathrm{N}$ value of the samples without formalin reached to $36.5 \mathrm{mg} / 100 \mathrm{~g}$ after 10 days of storage. On the other hand, the initial TVB-N value of the formalin added prawn was $7.0 \mathrm{mg} / 100 \mathrm{~g}$ and it was $33.0 \mathrm{mg} / 100 \mathrm{~g}$ after 10 days of iced storage. The TVB-N values of the formalin added samples were lower compared to non-added samples. This indicated that bacterial action in formalin added sample was low compared to non-added samples. The deteriorative changes in prawn muscle are possibly associated with the hydrolysis of cellular compounds by intracellular enzyme and bacterial enzyme during post-mortem period. Hydrolysis of protein and other nitrogenous compounds by autolytic enzyme together with bacterial action leads to an increased TVB-N value (Baldwin, 1961). There was a clear trend of increase in TVB-N value with the lapse of storage period.

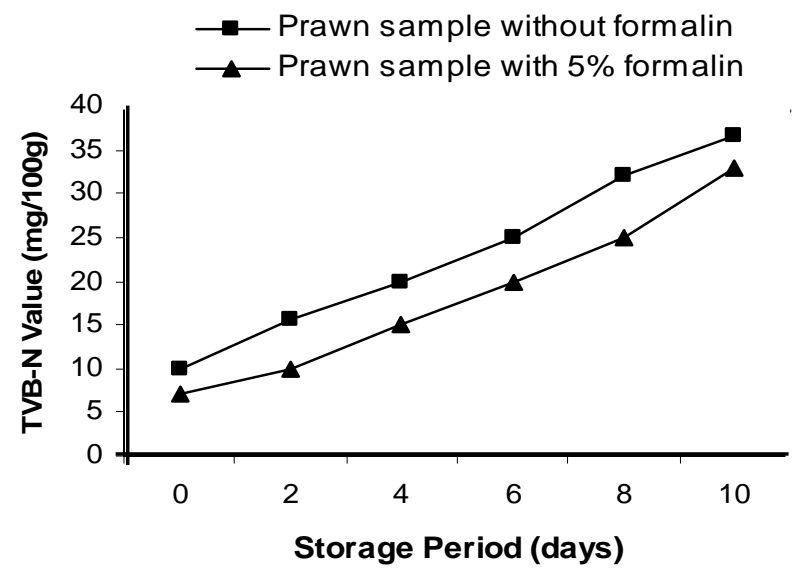

Fig. 2. Changes in TVB-N values of non-added and formalin added prawns under frozen storage

The TVB-N value may vary considerably from species to species and within the individuals of the same species due to variety of causes such as sex, age, season, feeding habit, spawning cycle etc. The results of the present study indicated that the low bacterial load in formalin added prawn during iced storage may be the main reason for low TVB-N value. There is a direct relationship between the bacterial load and TVB-N value; TVB-N value is higher with the higher bacterial load. Leitão and Rios (2000) reported that TVB-N content equal to $18.7 \mathrm{mg} / 100 \mathrm{~g}$ in fresh $M$. rosenbergii and $26 \mathrm{mg} / 100 \mathrm{~g}$ after 10 days of storage in ice. Acceptable limit of TVB- $\mathrm{N}$ for fish and shrimp is $30 \mathrm{mg} / 100 \mathrm{~g}$ muscle was reported by Connel (1995). Thus the present result reveals that the TVB-N value exceeded the acceptable limits and in agreement with the aforesaid discussion. 
Myofibrilar Protein Solubility: Changes in myofibrillar protein solubility of prawn samples during iced storage is presented in Fig. 3. In case of fresh prawn, initial myofibrillar protein solubility was found $88 \%$, which decreased gradually with the increasing of storage period. At the end of 10 days of iced storage, solubility decreased to around $44 \%$. On the other hand, Initial myofibrillar protein solubility of formalin added prawn was $80 \%$, which also decreased during the iced storage. At the end of 10 days of storage, myofibrillar protein solubility of formalin added prawn was $40 \%$. The overall solubility of myofibrillar protein of formalin added prawn was found lower than the non-added sample.

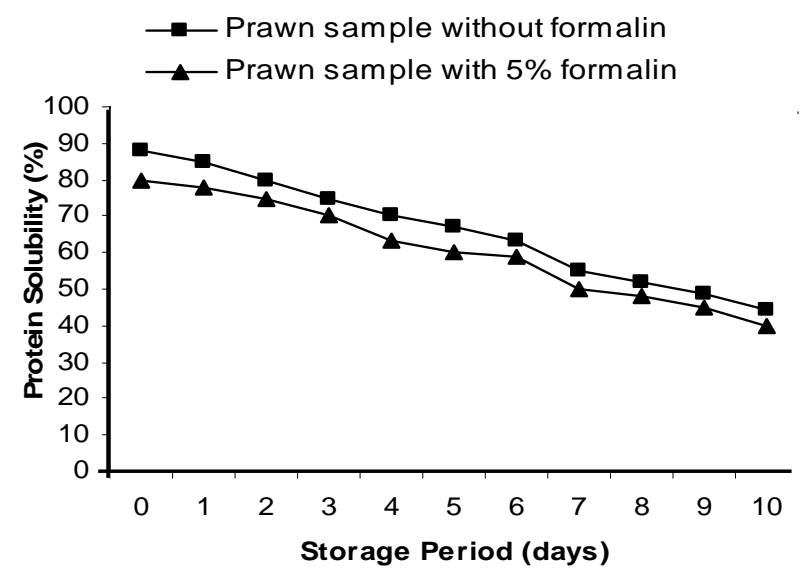

Fig. 3. Changes in myofibrillar protein solubility of non-added and formalin added prawns under iced storage

The result obtained from the present study is more or less in agreement with those reported for prawn and other fishes. Seki and Narita (1980) reported that solubility of carp myofibril decreased from 95 to $20 \%$ during iced storage within 2-3 weeks. The large fall in solubility during iced storage in fish muscle was caused by the decrease in pH (Penny, 1967; Kramer, 1981). Faruk (1995) reported that myofibrillar protein solubility of rohu (Labeo rohita) immediately after death was $87 \%$ which decreased gradually to $32 \%$ at the end of 24 days of iced storage. Kongpun et al. (2001) reported that different concentration of formalin solution affected myofibrillar protein of dorab meat (Chirocentrus dorab). However, the present study indicates that the use of formalin in prawn probably denatured the muscle protein considerably.

Bacteriological Analyses: Studies were also conducted on the quantitative changes in bacterial load in prawn ( $M$. rosenbergii) during iced storage. Aerobic plate count (APC) of both the samples under various storage times are presented in Table 4. Changes in bacterial load of both non-added and formalin added prawns in the form of log value are presented in Fig. 4.

Table 4. Quantitative changes in bacterial load of giant freshwater prawn (Macrobrachium rosenbergii) during iced storage

\begin{tabular}{|c|c|c|}
\hline \multirow{2}{*}{$\begin{array}{c}\text { Storage period } \\
\text { (days) }\end{array}$} & \multicolumn{2}{|c|}{ APC (CFU/gm ) } \\
\cline { 2 - 3 } & Non-added prawn & Formalin added prawn \\
\hline 0 & $3.02 \times 10^{6}$ & $7.60 \times 10^{5}$ \\
\hline 2 & $5.9 \times 10^{5}$ & $4.75 \times 10^{5}$ \\
\hline 4 & $1.42 \times 10^{6}$ & $3.08 \times 10^{5}$ \\
\hline 6 & $1.22 \times 10^{8}$ & $3.50 \times 10^{5}$ \\
\hline 8 & $1.33 \times 10^{8}$ & $4.60 \times 10^{5}$ \\
\hline 10 & $2.33 \times 10^{8}$ & $2.60 \times 10^{6}$ \\
\hline
\end{tabular}


Initial APC of non-added prawn samples was $3.02 \times 10^{6} \mathrm{CFU} / \mathrm{g}$. After 2 days of storage in ice the APC stood at $5.9 \times 10^{5} \mathrm{CFU} / \mathrm{g}$ and the prawns were in absolutely fresh condition with no sign of spoilage. The initial decrease in bacterial population in prawn after the first days of iced storage might be due to cold shock or leaching of surface flora by washing with melted ice. After 4 days in ice the APC stood at $1.42 \times 10^{6} \mathrm{CFU} / \mathrm{g}$. At this stage prawns in ice were still in fresh condition. After 6 days in ice, the APC increased further and prawns showed early signs of spoilage. After 10 days of iced storage, the APC was $2.33 \times 10^{8}$. However, at the end of 10 days of storage the bacterial load increased and at that the prawn became spoiled and the samples became organoleptically unacceptable.

Initial APC of formalin added prawn was $7.60 \times 10^{5}$ CFU/g. After 2 days of storage in ice the APC stood at $4.75 \times 10^{5} \mathrm{CFU} / \mathrm{g}$ and the prawns were in absolutely fresh condition with no sign of spoilage. After 4 days in ice the APC stood at $3.08 \times 10^{5} \mathrm{CFU} / \mathrm{g}$. At this stage prawns in ice were still in fresh condition. After 6 days in ice, the APC was $3.50 \times 10^{5}$ and prawns with no sign of spoilage. After 10 days in ice the APC was $2.60 \times 10^{6}$. The initial decrease in bacterial flora can be attributed to the longer lag phase of mesophilic species at cold temperature and washing effect of melting ice. At the end of 10 days of storage, the bacterial load increased and at that time the prawn became spoiled and the samples became organoleptically unacceptable.

$\square$ Prawn sample without formalin

Prawn sample with $5 \%$ formalin

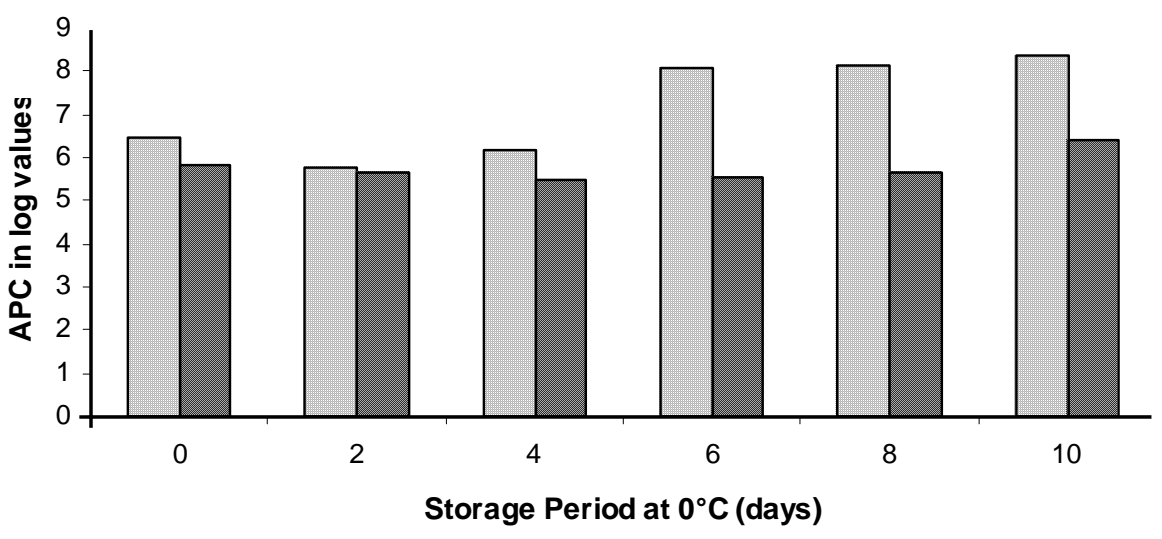

Fig. 4. Quantitative changes in bacterial load of non-added and formalin added prawn sample during iced storage

In the present study, delayed growth of bacterial in formalin added prawn during ice storage was observed due to the bactericidal effect of formalin. The growth was found prominent only during the longer storage period as by this time formalin was washed or leached away with the melting ice. Considerable reports are available on the changes in bacterial population during ice storages. Premaratne et al. (1986), reported an initial total plate count of $1.6 \times 10^{6} \mathrm{CFU} / \mathrm{g}$ for $M$. rosenbergii which increased to $8.6 \times 10^{7} \mathrm{CFU} / \mathrm{g}$ after 12 days iced storage. In an assessment of the shelf life of $M$. rosenbergii on the basis of microbial load, Angel et al. (1981) also found the sample in acceptable condition during first few days of iced storage.

\section{Conclusion}

In the present study, formalin added prawn preserved in ice was found organoleptically acceptable for longer period compared to non-added sample. Overall loss of freshness was due to gradual increase in expressible moisture content during frozen storage of prawn sample indicating some degree of protein denaturation. Myofibrilar protein of formalin added prawn was less soluble during iced storage which can be attributed to protein denaturing effect of formalin. Formalin added prawn also showed lower APC compared to non-added sample possibly due to its bactericidal effect. Though formalin improved the shelf life of freshwater prawn both in iced and frozen storage but it should not be used as preservative because of its association with many complex and fatal human health hazards. 


\section{References}

Angel, S., Basker, D., Dannier, J. and Juven, B.J. 1981. Assessment of shelf-life of freshwater prawns stored at $0^{\circ} \mathrm{C}$. J. Food Technol. 16: 357-366.

Anon, A.O. 1972. DIFCO manual of dehydrated culture media and reagents for microbiological and clinical laboratories procedures, $9^{\text {th }}$ ed., p. 212-231. DIFCO Laboratories Detroit, Michigan.

AOAC. 1980. Official Methods of Analysis, $13^{\text {th }}$ ed. Association of Official Analytical Chemists. Washington, DC.

Babbitt, J.K., Law, D.K. and Crawford, D.L. 1974. Acceptance of a fish-shrimp portion utilization machine separated minced fish flesh. J. Food Sci. 39: 1130-1131.

Baldwin, E. 1961. Synthesis of nitrogenous end-products: Trimethlyleamine and Trimethylamine oxide. In: Dynamic aspects of biochemistry. $5^{\text {th }}$ ed., London, Cambridge university press. p. 227.

Barrow, G.I., Feltham R.K.A., (eds.). 1993. Cowan and Steel's Manual for the Identification of Medical Bacteria, $3^{\text {rd }}$ ed., Cambridge, Cambridge University Press. p. 214-218.

Bremner, H.A., Olley, J. and Vail, A.M.A. 1987. Estimating time-temperature effects by a rapid systematic sensory method. In: D.E. Kramer and J. Liston (eds.) Seafood Quality Deter-mination, Amsterdam, Elsevier. p. 413-435.

Cann, D.C. 1974. Bacteriological aspects of tropical shrimp. In: R. Kreuzer, (ed.) Fishery products \& wastes by fleet, England, Fishery News Books. p. 338-344.

Connel, J.J. 1995. Control of fish quality-Proposed limit for acceptability for Marine species, $4^{\text {th }}$ ed., Fishing News Books Ltd., Surrey, England. p. 279.

Cornall, A.G., Bardawill, C. J. and David, M.M. 1949. Determination of serum proteins by means of the biuret reaction. J. Biol. Chem. 177: 751-766.

Cramer, J.L., Akamuraa, R.M.N., Diuin, E. and Kehara, W.N.I. 1981. Brunt tuna: Conditions leading to rapid deterioration in the quality of raw tuna. Mar. Fish. Rev. 43(6): 12-16.

European Communities (EC). 1995. Determination of the concentration of volatile nitrogenous bases (TVBN) in fish and fish products: A reference procedure. O.J. E.C. p.15.

Faruk, M.A.R. 1995. Studies on the post-mortem changes in Rohu fish (Labeo rohita). M.S. Thesis, Department of Fisheries Technology, Bangladesh Agricultural University, Mymensingh, Bangladesh, $47 \mathrm{pp}$.

Fatima, R., Khan, M.A. and Qadri, R.B. 1988. Shelf-life of shrimp Penaeus merguiensis stored in ice $\left(0^{\circ} \mathrm{C}\right)$ and partially frozen ($\left.3^{\circ} \mathrm{C}\right)$. J. Sci. Food Agric. 42: 235-247.

Garner, A., Silvia, J.L., Chemul, R.S. and Barrero, M. 2002. Influence of phosphate type of corporation on physical, chemical and sensory characteristics of channel catfish fillets. Paper presented in Annual Meeting on Food Export, Anaheim, California.

Hudson, W.R., Roberts, T.A. and Whelehan, O.P. 1983. A minimal apparatus method for counting bacteria: comparison with reference method in surveying beef carcasses at three commercial abattoirs. J. Hyg. Camb. 91: 459-466

Hussain, M.M. and Uddin, M.H. 1995. Quality control of marketing of fish products: Needs of infrastructure and legal support. Paper presented in the national workshop on Fisheries Resources, October 29 to November 01, Dhaka, Bangladesh.

Kamal, M., Rahman, M.M., Yasmin, L., Ahmed, S.U. and Islam, M.N. 2000. Studies on the post-mortem changes in shrimp and prawn during ice storage: II. Biochemical aspects of quality changes. Bangladesh J. Fish. Res. 4: 91-96.

Kamal, M. and Islam, N. 2000. Improved handling and preservation of golda (Macrobrachium rosenbergii) for producing safe and wholesome products. Project report. Dept. of Fisheries Technology, Bangladesh Agricultural University, Mymensingh. p. 4-9.

Kitchens, J.F., Casner, R.E., Harwood, W.E., Macri, B.J. and Edwards, G.S. 1995. Investigations of selected potential environmental contaminants: formaldehyde. TS-USEPA Washington D.C. 204 pp.

Kongpun, O., Suwansakomkul, P. and Predalumpabut, P. 2001. Effect of formaldehyde on the gel forming ability of fish meat. Kasetsart J. Nat. Sci. 35(3): 318-325.

Leitão, M.F.F. and Rios, D.P. 2000. Microbiological and chemical changes in freshwater prawn (Macrobrachium rosenbergii) stored under refrigeration. Braz. J. Microbiol. 31: 178-183.

Matheson, J.C. 1981. Environmental assessment of formalin as a parasiticide and fungicide in fish culture. (NADA 137-687 and MF 3543).

Mazid, M.A. and Mostafa. M.G. 2009. Training Manual on Good Aquaculture Practices for Quality Control and Food Safety in Shrimp. Bangladesh quality support program-Fisheries, UNIDO, Dhaka, Bangladesh. $111 \mathrm{pp}$.

$\mathrm{Ng}$, C.S. and Hasegawa, H. 1987. Measurement of free and expressible drips. In: H. Hasegawa (ed.), Laboratory manual on analytical methods and procedures for fish and fish products. Part A-4, p.1-2. Marine Fisheries Research Department, Southeast Asian Fisheries Development Center, Singapore.

Penny, I.F. 1967. The influence of pH and temperature on the properties of myosin. Biochem. J. 104: 609-615. 
Perry, S.V. and Grey, T.C. 1956. Ethylene-diamine-tetraacetate and the adenosine-tryphosphatase activity of actomyosin systems. Biochem. J. 64: 184.

Premaratne, R.J., Nip, W.K. and Moy, J.H. 1986. Characterization of proteolytic and collagenolytic psychro-tophic bacteria in ice stored fresh water prawn. Mar. Fish. Rev. 48: 44-71.

Rahaman, M., Yasmin, L., Kamal, M., Mazid, M.A. and Islam, M.N. 2001. Effect of delayed icing on the quality changes in brackish water shrimp Penaeus monodon during ice storage. Pak. J. Biol. Sci. 4: 1390-1394.

Reddy, G.V.S. and Srikar, L.N. 1991. Preprocessing ice storage effects on functional properties of fish mince protein. J. Food Sci. 56: 965-968.

Reilly, A., Bernarte, M.A. and Dangla, E. 1985. Quality changes in brackish water prawns (Penaeus monodon) during storage at ambient temperature in ice and after delays in icing. In: A. Reilly, ed. Spoilage of Tropical Fish and Product Development, p. 133-145. FAO Fisheries Report No. 317, FAO, Italy, Rome.

Ruan, R. and Chen, P. 1998. Water in foods and biological materials- a nuclear magnetic resonance approach. Lancaster, Pennsylvania, USA, and Basel, Switzerland, Technomic Publishing Co. Inc. 307 pp.

Seki, N. and Narita, N. 1980. Changes in ATPase activities and other properties of carp myofibrillar protein during iced-storage. Bull. Jpn. Soc. Sci. Fish. 46: 207-213.

Shewan, J.M. and Ehrenberg, R.T. 1977. The bacteriology of fresh and spoilage fish and the biochemical changes induced by bacterial action. In: P. Sutcliffe and J. Disney (eds.), Handling, Processing and Marketing of Tropical Fish, Tropical Products Institute, London, U.K. p. 51-66.

Sikorski, E.Z, Kolakowska, J., and Burt, J.R. 1994. Cambios bioquímicosy microbianos subsiguientes a la captura. In: Z.E. Sikorski, ed. Tecnologia de los productos del mar: recursos, composicion nutritiva y conservación, Editoral Acribia, S.A. Zaragoza, España. p. 75-101.

Suvanich, V., Jahncke, M.L. and Marshall, D.L. 2000. Changes selected chemical quality characteristics of channel catfish frame mince during chill and frozen storage. J. Food Sci. 65(1):24-29.

Tarr, H.L.A. 1965. Chemical control of Microbiological Decomposition. In: G. Borgstrom, (ed.) Fish as Food, New York, Academic Press. Vol. 1. p. 639-680.

UNIDO (United Nations Industrial Development Organization), 1992. Measures of Increase the Production and Marketing of Value Added Fish Products in Asia and the Pacific Island Countries. Proceedings of Regional Consultation on the Fisheries Industry for Asia and Pacific Inland Countries, Vienna, 2-6.

Wooster, G.A., Martinez, C.M. and Bowser, P.R. 2005. Human health risks associated with formaldehyde treatments used in aquaculture: Initial study. N. AM. J. Aquacult. 67: 111-113.

Yamagata, M. and Low, L.K. 1995. Banana shrimp, Penaeus merguiensis, quality changes during iced and frozen storage. J. Food Sci. 60: 721-26. 